\title{
How to Deal with Uninvited Guests in Wine: Copper and Copper-containing Oxidases
}

\author{
Harald Claus
}

Institute of Molecular Physiology, Microbiology \& Wine Research, Johannes Gutenberg University of Mainz, Becherweg 15, D-55099 Mainz, Germany; hhclaus@arcor.de

Received: 4 March 2020; Accepted: 15 March 2020; Published: 24 March 2020

\begin{abstract}
Copper is one of the most frequently occurring heavy metals in must and wine. It is introduced by pesticides, brass fittings, and as copper sulphate for treatment of reductive off-flavors. At higher concentrations, copper has harmful effects on the wine. It contributes to the oxidation of wine ingredients, browning reactions, cloudiness, inhibition of microorganisms, and wine fermentation. Last but not least, there is also a danger to the consumer. At present, some physicochemical methods exist to reduce the copper content in must and wine, but they all have their shortcomings. A possible solution is the biosorption of metals by yeasts or lactobacilli. Copper can also reach must and wine in the form of copper-containing phenol oxidases (grape tyrosinase, Botrytis cinerea laccases). Similar to free copper, they oxidize phenolic wine compounds, and thus lead to considerable changes in color and nutritional value, making the product ultimately unsaleable. All measurements for enzyme inactivation such as heat treatment, and addition of sulphites or bentonite are either problematic or not effective enough. The application of oenological tannins could offer a way out but needs further research.
\end{abstract}

Keywords: wine browning; copper casse; phenoloxidases; bentonite; tannins; biosorption

\section{Introduction}

Many wine constituents including phenols are susceptible to oxygen, and thus lead to the development of oxidation products during vinification [1,2]. Wine browning is one of the most common problems that occurs during winemaking and affects color and sensory characteristics, and also leads to loss of nutritional values of the wine [3]. Wine browning is caused by enzymatic and non-enzymatic oxidations. Non-enzymatic oxidation occurs in wine by direct reaction of phenols with air. Iron and copper play an important catalytic role. Enzymatic oxidation in must and wine takes place under the influence of copper-containing enzymes (tyrosinase and laccase) [4-7]. An excess of free copper cations also has negative effects on wine microorganisms, wine fermentation, and last but not least, on the health of the consumer. Therefore, there is an urgent need to minimize the concentration of copper and activities of copper-containing oxidases in must and wine. This review describes the effects of copper (oxidases) on wine quality and presents some possible countermeasures.

\section{Copper}

Copper is an essential trace element involved in many natural metabolic processes of living organisms. It plays a major role in redox reactions and oxygen transport, contributes to the biological energy production of cells, and is an important component of enzymes [8]. The WHO guideline for drinking water was set at $2 \mathrm{mg} / \mathrm{L}$, as a figure considered to be safe for chronic population exposure $[9,10]$. However, an elevated copper level leads to disorders of liver metabolism, increased formation of free radicals, and can also promote disorders of the central nervous system [9]. The physiological oxidation 
states of copper are $\mathrm{Cu}^{1+}$ and $\mathrm{Cu}^{2+}$, whereas $\mathrm{Cu}^{3+}$ is not a biologically relevant species because of the high redox potential of the $\mathrm{Cu}^{3+} / \mathrm{Cu}^{2+}$ couple [8].

\subsection{Occurrence and Effects of $\mathrm{Cu}$ in Must and Wine}

The advantages of copper as a widely applicable fungicide are countered by the problem of soil contamination. Vineyard areas that have been treated with copper preparations over several decades sometimes have high excessive copper contents that exceed the EU permissible limit value $(140 \mathrm{mg} / \mathrm{kg})$ several times [11].

Copper is also one of the most frequently occurring heavy metals in wine and can reach the wine via pesticides, brass fittings, and as copper sulphate for treatment of reductive off-flavors [12,13]. According to a study in which 72 wines were analyzed, the average copper content was $0.18 \mathrm{mg} / \mathrm{L}$ with a maximum of $0.55 \mathrm{mg} / \mathrm{L}$ [10]. The Organisation International de la Vigne et du Vin (OIV) recommends a maximum copper content of $1.0 \mathrm{mg} / \mathrm{L}$ for wines [14]. National regulations allow the presence of $2.0 \mathrm{mg} / \mathrm{L} \mathrm{Cu}$, in German wines [10]. Possible negative consequences of increased copper contents in must and wine, as well as corresponding limits are summarized in Table 1.

Copper casse (haze) can develop after wine bottling in the absence of oxygen, presence of sulfur dioxide and copper contents $>0.5 \mathrm{mg} / \mathrm{L}$. It is composed of cupric and cuprous sulfides which form a reddish haze or deposit especially in white wine and less in rosé wines [12,13].

Table 1. Copper concentrations in must and wine with corresponding effects [15].

\begin{tabular}{cc}
\hline Limits and Normal Values/Effects & Cu Concentration (mg/L) \\
Normal value in wine & $0.7-0.8$ \\
Maximum content allowed in wine & 2.0 \\
Concentration range in must & $0.09-0.99$ \\
Copper casse & in traces \\
Copper catalyzed oxidations (browning reaction) & $>0.5$ \\
Influencing fermentation of sparkling wine (very rare) & 20 \\
Sluggish must fermentation & $25-50$ \\
Inhibition of Oenococcus oeni Microenos B1 & $5^{*} ; 10^{* *}$ \\
Inhibition of Saccharomyces cerevisiae SN9 / SN41 / CCT0472 & $32 / 320 / 75$ \\
Inhibition of Lactobacillus fermentum CCT1400 / CCT0559 & $75 / 300$ \\
Inhibition of Lactobacillus mesenteroides CCT0582 / CCT0367 & $75 / 150$ \\
\hline
\end{tabular}

${ }^{*}$ Copper as $\mathrm{CuSO}_{4} \times 5 \mathrm{H}_{2} \mathrm{O} ;{ }^{* *}$ Copper as $\mathrm{CuCl}_{2} \times 2 \mathrm{H}_{2} \mathrm{O}$.

\subsection{Measurements to Reduce Cu Concentrations in Must and Wine}

\subsubsection{Chemical and Physical Methods}

If the remaining copper content exceeds the permitted limits, metal removal procedures must be applied. In the so-called "blue fining" process, potassium ferrocyanide II is added to the wine, which forms an insoluble complex with copper ions that precipitates the copper. The remaining cyan compounds, then, react with the iron already present and precipitate [12,13]. In the case of iron deficiency, an excess amount of potassium hexacyanoferrate II remains in the wine, making it usuitable for consumption. A further disadvantage of blue fining is the resulting toxic hazardous waste, which must be disposed of separately and at great expense.

Another procedure is the use of the natural plant polysaccharide gum arabicum which presents the most applied protective colloid in winemaking authorized within the European Union. It is used at a dosage of 10 to $15 \mathrm{~g} / \mathrm{hL}$ to prevent copper casse, as long copper levels do not exceed $1.0 \mathrm{mg} / \mathrm{L}$ [16]. The colloid prevents metal precipitation but does not eliminate the copper. Because clarification of a wine treated with gum arabicum is difficult, it is generally mixed into the wine just before bottling [16]. 
Apart from plant resins, artificial exchange resins have been developed to overcome the disadvantageous use of traditional bluefining. These include polyvinylimidazole-polyvinylpyrrolidone copolymers (PVI/PVP) to combine the benefits of PVPP with selective binding of metals such as copper or iron $[17,18]$. In that case, special care must be taken to avoid possible migration of unpleasant monomers or degradation products into the wine $[17,18]$.

With the aim of preventing turbidity, bentonite is often used to remove proteins (see Section 3.3.4) and also copper from the wine. However, this process can exert adverse effects on color and the taste of the wine [19].

\subsubsection{Biosorption}

An alternative method for metal removal is biosorption (Table 2). This is a passive, non-metabolic process in which, for example, heavy metals are bound to biomass (bacteria, fungi, and algae) [20-26]. For a suitable application in winemaking, preference is given to microorganisms for which wine represents a natural habitat and which are not harmful to consumers, for example, wine yeasts [20,21]. Other candidates in this respect are lactobacilli [22] which are regularly found on grapes, as well as in must and wine [27].

Table 2. Compilation of biosorbent materials and their maximum specific copper binding capacity (qh) [20-26].

\begin{tabular}{|c|c|c|c|}
\hline Biosorbent & pH Optimum & $\begin{array}{l}\text { Biomass Added } \\
(\mathrm{mg} / \mathrm{mL})\end{array}$ & $\left(\mu \mathrm{g} \mathrm{Cu}{ }^{2+} / \mathrm{qh}\right.$ Cells $)$ \\
\hline \multicolumn{4}{|l|}{ Bacteria } \\
\hline Arthrobacter sp. & $3.5-6.0$ & 0.4 & 148.0 \\
\hline Bacillus sp. (ATS-1) & 5.0 & 2.0 & 16.3 \\
\hline Bacillus subtilis IAM 1026 & 5.0 & 0.5 & 20.8 \\
\hline Enterobacter sp. J1 & 5.0 & 1.0 & 32.5 \\
\hline Lactobacillus brevis ID9262 & 5.0 & 0.5 & 26.5 \\
\hline $\begin{array}{l}\text { Lactobacillus buchneri DSM } 20057 \\
\text { (living / dead) }\end{array}$ & 5.0 & 1.0 & $10.5 / 9.9$ \\
\hline $\begin{array}{c}\text { Lactobacillus hilgardii } \\
\text { DSM } 20176 \text { (living/dead) }\end{array}$ & 5.0 & 1.0 & $10.0 / 8.8$ \\
\hline $\begin{array}{l}\text { Lactobacillus plantarum } \\
\text { DSM } 20174 \text { (living /dead) }\end{array}$ & 5.0 & 1.0 & $9.7 / 8.6$ \\
\hline Lactobacillus plantarum ID9263 & 5.0 & 0.5 & 15.5 \\
\hline $\begin{array}{l}\text { Lactobacillus vini DSM } 20605 \\
\text { (living/dead) }\end{array}$ & 5.0 & 1.0 & $12.3 / 9.7$ \\
\hline Leuconostoc mesenteroides ID9261 & 5.0 & 0.5 & 26.3 \\
\hline Micrococcus luteus & 5.0 & 0.5 & 33.5 \\
\hline Pseudomonas aeruginosa PU21 & 5.0 & 1.0 & 23.1 \\
\hline Pseudomonas cepacia & 7.0 & n. d & 65.3 \\
\hline Pseudomonas putida & 6.6 & n. a. & 6.6 \\
\hline Pseudomonas putida CZ1 & 4.5 & 1.0 & 15.8 \\
\hline Pseudomonas stutzeri IAM 12097 & 5.0 & 1.0 & 22.9 \\
\hline Pseudomonas stutzeri KCСM 34719 & 5.0 & 1.0 & 36.2 \\
\hline Pseudomonas syringae & n.d. & 0.28 & 25.4 \\
\hline Sphaerotilus natans & 5.5 & n.d. & 5.4 \\
\hline Streptomyces noursei & 5.5 & 3.5 & 9.0 \\
\hline Synechocystis sp. & 4.5 & 1.0 & 23.4 \\
\hline Zoogloea ramigera & 5.5 & 0.83 & 270.0 \\
\hline Zoogloea ramigera & 4.0 & n. $\mathrm{d}$ & 29 \\
\hline \multicolumn{4}{|l|}{ Yeasts } \\
\hline Cryptococcus terreus & 5.5 & 1.0 & 71.8 \\
\hline Pichia guilliermondii & 5.5 & 1.0 & 34.0 \\
\hline Saccharomyces cerevisiae ${ }^{1)}$ & 5.5 & 1.0 & 43.3 \\
\hline Saccharomyces cerevisiae $^{2)}$ (living/dead) & 4.0 & 2.0 & $0.8 / 0.4$ \\
\hline
\end{tabular}


Copper, which is present in wine in combination with other heavy metals ( $\mathrm{Mn}, \mathrm{Zn}, \mathrm{Ni}, \mathrm{Pb}$, and $\mathrm{V}$ ), poses health risks for the consumer [28] and for wine quality [1,2]. For these reasons, our laboratory studied the potential of oenological lactobacilli for metal biosorption under wine-like conditions [15,24].

Of the nine wine-relevant test strains, L. buchneri DSM 20057, L. vini DSM 20605, L. hilgardii DSM 20176, and L. plantarum DSM 20174 showed the highest binding capacity under standard conditions in water (Figure 1). The physiological state of the cells plays an important role in biosorption. The absence of metabolism and of a proton gradient leads to a negatively charged cell surface in dead cells, and thus often to a higher affinity for metal cations [22,23]. In our previous work, lyophilized cells (living or boiled for $1 \mathrm{~h}$ ) did not show major differences in this respect. However, autoclaved biomass (15 min, $121^{\circ} \mathrm{C}$ ) displayed a significantly lower adsorption capacity (Figure 1). This harsh treatment probably led not only to inactivation of cell metabolism but also to damage of the cell structure.

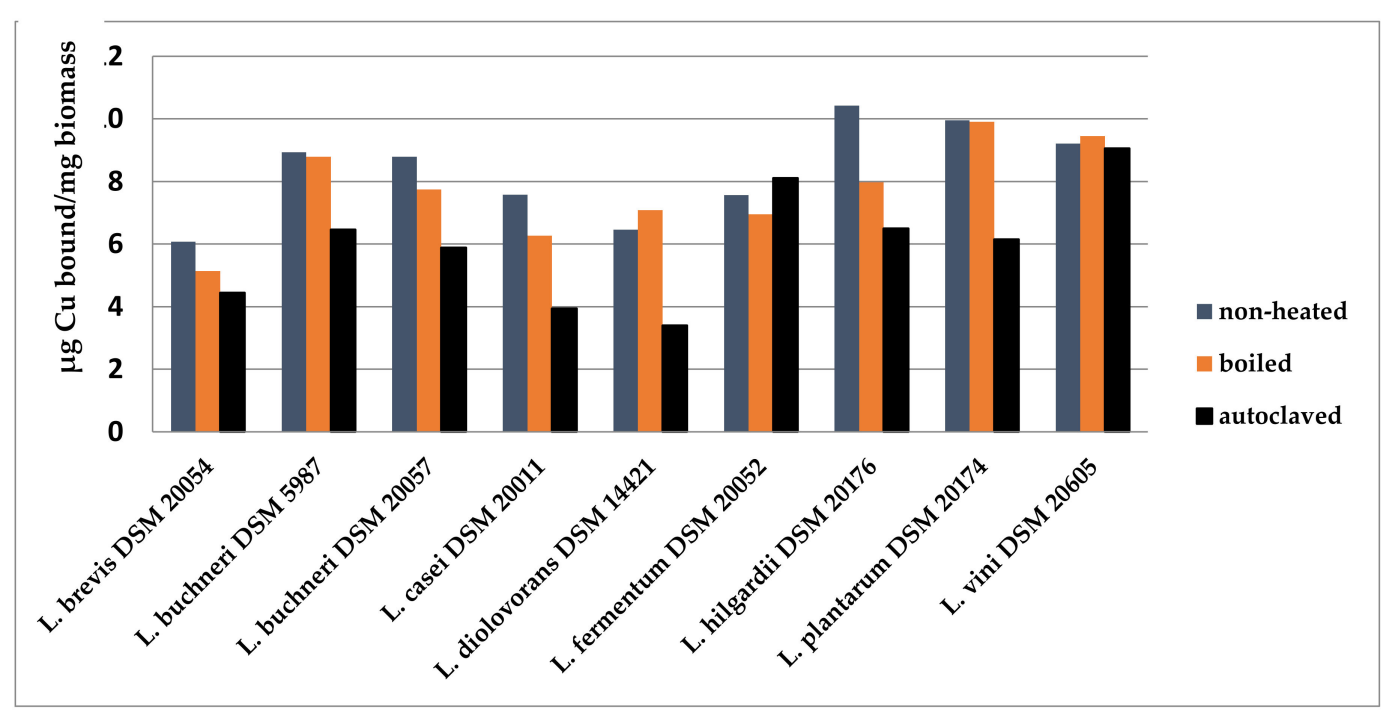

Figure 1. Effect of heat treatment on the copper binding capacity of wine-relevant Lactobacillus species. Conditions: Deionized water at pH 5.0 with $40 \mu \mathrm{g} \mathrm{Cu}^{2+} / \mathrm{mL}$, biomass concentration $1 \mathrm{mg} / \mathrm{mL}$, and incubation time $1 \mathrm{~h}[15,24]$.

The maximum binding capacity with inactivated cells was generally reached after $30 \mathrm{~min}$ (data not shown). At this time, the system reached a dynamic equilibrium where the number of adsorbed metal ions equaled the number of desorbed ions [25]. As the $\mathrm{pH}$ of the solution increased, the binding capacity of the lactobacilli for $\mathrm{Cu}$ also increased (Figure 2), probably due to a larger number of negatively charged carboxyl and phosphate groups on the cell surface [29].

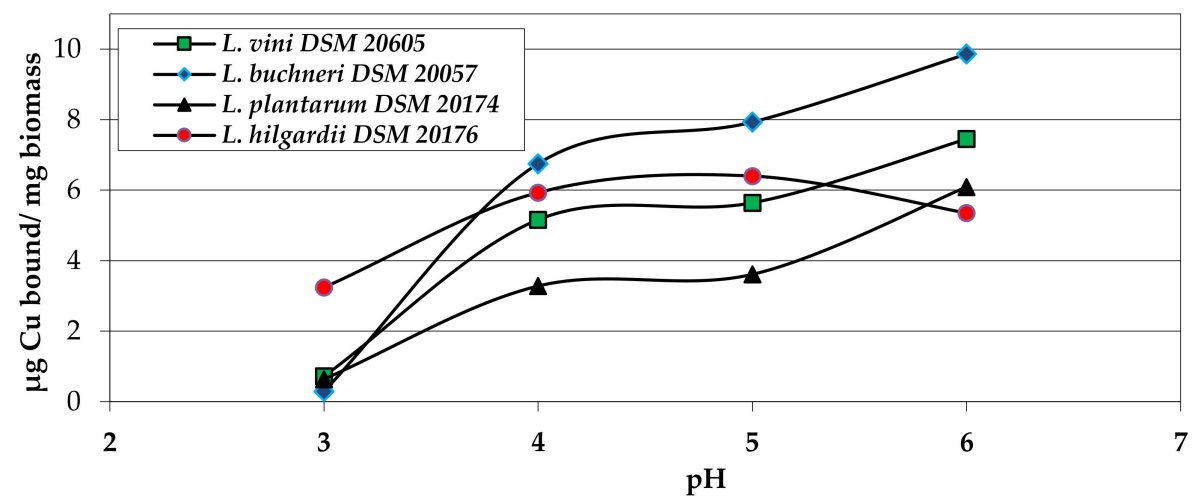

Figure 2. Effect of the matrix $\mathrm{pH}$ on the copper binding capacity of wine-relevant Lactobacillus species. Conditions: Deionized water with $40 \mu \mathrm{g} \mathrm{Cu}{ }^{2+} / \mathrm{mL}$, biomass concentration $1 \mathrm{mg} / \mathrm{mL}$ (boiled cells), and incubation time $30 \mathrm{~min}[15,24]$. 
Several authors have described a pH of 5.0 as optimal for the metal biosorption by lactobacilli [30,31]. Although at even higher $\mathrm{pH}$ values more negatively charged functional groups would be available, these conditions are remote and unsuitable, as they promote formation of insoluble copper(II) hydroxides and precipitates. Under acidic conditions, the copper bond was significantly reduced. At a $\mathrm{pH}$ of 3.0, L. hilgardii DSM 20176 showed the highest Cu-bond among the test strains with $3.2 \mu \mathrm{g}$ to $4.2 \mu \mathrm{g}$ $\mathrm{Cu}^{2+} / \mathrm{mg}$ biomass. The comparison of the biosorption of different metals showed that the binding capacity for $\mathrm{Cu}$ was highest, followed by $\mathrm{Zn}, \mathrm{Fe}$, and $\mathrm{Mn}$ (data not shown).

The extent of absolute metal removal correlated with biomass concentration. However, at biomass concentrations $>2 \mathrm{mg} / \mathrm{mL}$ cell aggregates were formed, which resulted in a reduction of the specific adsorption [32].

The biosorption of $\mathrm{Cu}$ is a function of its concentration in the medium. As derived from Langmuir isotherms (Figure 3), the maximum adsorption capacity (Qmax) of the test strains was about 11 to $46 \mu \mathrm{g} \mathrm{Cu} / \mathrm{mg}$ biomass.

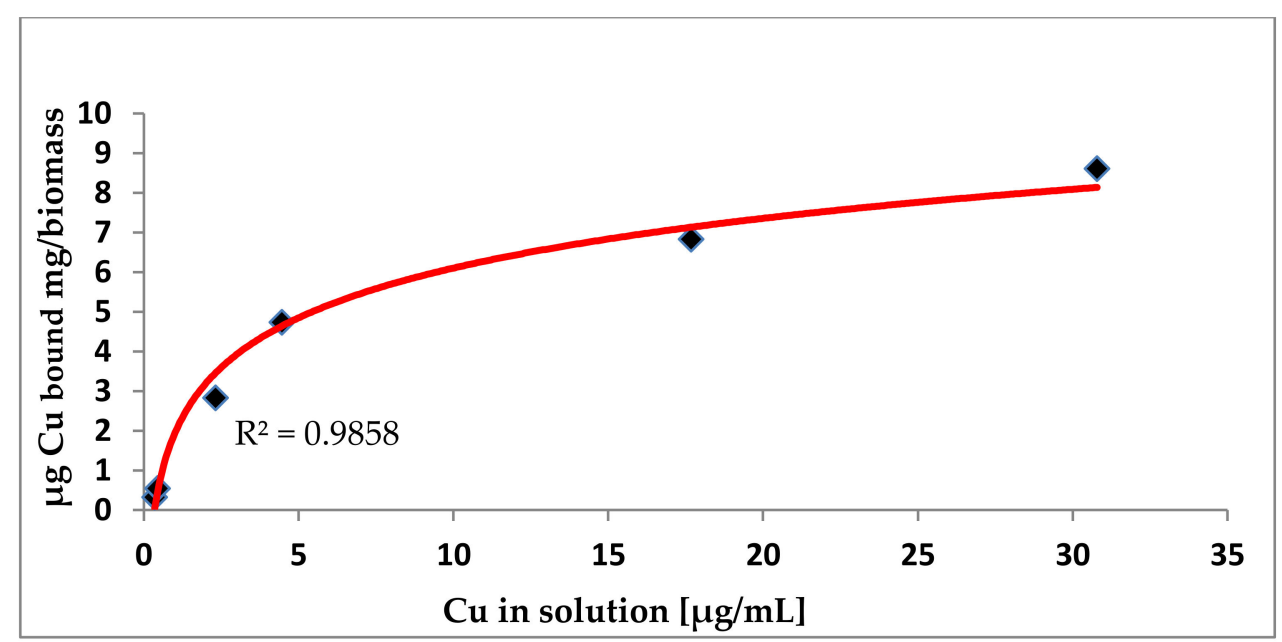

Figure 3. Adsorption isotherm for copper binding by boiled biomass of L. plantarum DSM 20174. Conditions: Deionized water at $\mathrm{pH} 5.0$ with 0.04 to $40 \mu \mathrm{g} \mathrm{Cu}^{2+} / \mathrm{mL}$, biomass concentration $1 \mathrm{mg} / \mathrm{mL}$, and incubation time $30 \mathrm{~min}$. [15,24].

The copper binding capacity by Lactobacillus cells was compared at the same $\mathrm{pH}(5.0)$ in a white wine, grape juice, and deionized water (Table 3).

Table 3. Removal of copper from must and wine by living biomass of L. buchneri DSM 20057.

\begin{tabular}{|c|c|c|c|c|}
\hline \multirow[b]{2}{*}{ Medium } & \multirow[b]{2}{*}{$\mathrm{pH}$} & \multicolumn{2}{|c|}{$\mu \mathrm{g} \mathrm{Cu}{ }^{2+} / \mathrm{mL}$ in Solution } & \multirow{2}{*}{$\mu \mathrm{g} \mathrm{Cu}{ }^{2+} / \mathrm{mL}$ Removed (\%) } \\
\hline & & Control & $\begin{array}{c}\text { + L. buchneri } \\
\text { DSM } 20057\end{array}$ & \\
\hline Water & 5.0 & 3.90 & 0.76 & $3.14(81.0)$ \\
\hline Must (white) & 3.5 & 5.64 & 5.20 & $0.44(7.8)$ \\
\hline Must (red) & 3.6 & 4.17 & 3.96 & $0.21(5.0)$ \\
\hline Wine (white) & 3.3 & 4.16 & 3.60 & $0.56(13.5)$ \\
\hline Wine (red) & 3.1 & 3.89 & 2.86 & $1.03(26.5)$ \\
\hline
\end{tabular}

In general, the biosorption in must and grape juice was much lower than in water. Obviously, an acidic $\mathrm{pH}$ is not the only reason for the lower $\mathrm{Cu}$-binding in must and wine as compared with water. Wine-typical constituents such as organic acids, phenolic compounds, and proteins influence the properties of the cell surface and compete for the metal ions. Furthermore, some of the functional groups could have been occupied by different metal cations already present in must and wine. Nevertheless, 
about 0.5 to $1.0 \mu \mathrm{g} \mathrm{Cu} / \mathrm{mL}$ could be removed from white and red wine by cells of L. buchneri DSM 20057 (Table 3). Mira et al. [18] used a copolymer of vinylpyrrolidone and vinylimidazole (PVI-PVP) for metal reduction in wine. At a concentration of $0.5 \mathrm{mg} / \mathrm{mL}$, PVI-PVP removed $0.59 \mu \mathrm{g} \mathrm{Cu} / \mathrm{mL}$ and $0.74 \mu \mathrm{g} \mathrm{Cu} / \mathrm{mL}$ from a white and red wine, respectively, i.e., at approximately the same level as by biosorption.

\section{Copper-Containing Oxidases}

Both spontaneously and enzymatically catalyzed oxidations have dramatic effects on the final phenol composition from the grape berry up to the bottled wine. Once the berry integrity has been destroyed, oxidative enzymes (phenoloxidases) and their phenolic substrates are exposed to air which results in enzymatic browning. The responsible copper-containing enzymes tyrosinase and laccase use molecular oxygen for substrate oxidation and [8]tyrosinase (E.C. 1.14.18.1) hydroxylates monophenols to ortho-diphenols and oxidizes the latter to orthoquinone intermediates which polymerize to form brown pigments. Laccase (EC 1.10.3.2) has no monohydroxylase activity but oxidizes a wide spectrum of different polyphenols and other compounds by a radical mechanism. Tyrosinase is produced by grape berries [6], whereas laccases in must and wine originate from epiphytic fungi [4,5]. Due to their high stability and broader substrate range laccases appear to be a more serious threat for winemaking than tyrosinases [7].

\subsection{General Features of Laccases}

Laccases (EC 1.10.3.2, p-benzenediol: oxygen oxidoreductases) are multi-copper proteins that use molecular oxygen to oxidize their substrates with the formation of water $[4,5,33]$. The enzyme was first discovered in the Japanese and Chinese lacquer tree (Rhus sp.), and thus received its trivial name due to the source of its discovery. The enzyme was subsequently found in many other eukaryotes (fungi, insects, and arthropods) and later also in prokaryotes $[4,5,33]$. Laccases have different functions. They are involved in the defence, pathogenicity, and morphogenesis of organisms. In woody plants, they participate in lignin biosynthesis, whereas in many basidiomycetes they are involved in lignin degradation $[4,5,33]$.

Laccases have a broad substrate spectrum which include natural monomeric and polymeric phenols, halogenated aromatics, aromatic amines, tyrosine residues in proteins, and even some metals. The range of oxidizable substrates is further extended by the mediation of low-molecular redox mediators. The fungal laccases have their $\mathrm{pH}$ optimum mostly in the acidic range, for example, Botrytis cinerea at 3.5. The isoelectric points of these enzymes are also in the acidic $\mathrm{pH}<4.0$. Usually, fungi produce several glycosylated isoforms with molecular masses around $60 \mathrm{kDa}[4,5,33]$.

Laccases are stable in many organic solvents, act relatively unspecifically, do not need any cofactors except copper, and use oxygen from the atmosphere as an electron acceptor. These properties make laccase very attractive for practical applications in industrial biotechnology and environmental technology [33]. In the wine sector, for example, they have been proposed to avoid cork taint. This is mainly produced by 2,4,6-trichloroanisole (TCA), a phenol derivative with a mouldy odour. By washing the cork with Suberase ${ }^{\circledR}$ solution (=laccase), phenols and their derivatives such as TCA, which are responsible for the cork off-flavor are polymerized, and thus eliminated. Laccase is also used for beverage stabilization of fruit juices, where the targeted removal of phenols is its main role $[4,33]$.

\subsection{The Impact of Botrytis Cinerea Laccases on Wine Quality}

Botrytis cinerea is a phytopathogenic fungus that infects over 200 economically important plant species and causes considerable losses. Whether the fungus has a positive or negative effect on wine quality depends not only on the ripeness of the infested berries but also on weather conditions. During the infection process, the fungus produces various cell wall dissolving exoenzymes (lipases, cutinases, and proteinases). Laccases play a protective role by oxidizing and inactivating phenolic plant defences 
(phytoalexins) such as resveratrol $[4,5]$. The enzyme is a considerably stable protein which can enter must and wine in an active form.

Red grapes contain a large number of phenols (ranging from ca. 1.0 to $3.0 \mathrm{~g} / \mathrm{L}$ ) which essentially influence the color, smell, and taste of the wine [34]. In addition to their visual and gustatory properties, phenols act as radical scavengers and have an antioxidant effect. Some also have cancer-preventing, anti-inflammatory, antibacterial, and anti-hepatotoxic activities. Therefore, phenols are of great health significance [34]. Due to its phenol oxidase activity, laccase has, thus, a detrimental impact on qualitative and nutritional values of infected wines and makes such products unsaleable.

\subsection{Strategies to Eliminate Laccase Activities in Must and Wine}

\subsubsection{Heat Treatment}

One possibility to inactivate this enzyme is the short-term heating of the must. De Leonardis et al. [35] showed that the laccase of Trametes versicolor was completely inactivated after heating for one minute at $100{ }^{\circ} \mathrm{C}$ or three minutes at $80^{\circ} \mathrm{C}$. Figure 4 shows the effect of temperature on an intrinsic must laccase [36]. A brief heating of the must $\left(2 \mathrm{~min}\right.$ at $\left.75^{\circ} \mathrm{C}\right)$ led to complete inactivation. Lower temperatures required correspondingly longer exposure times.

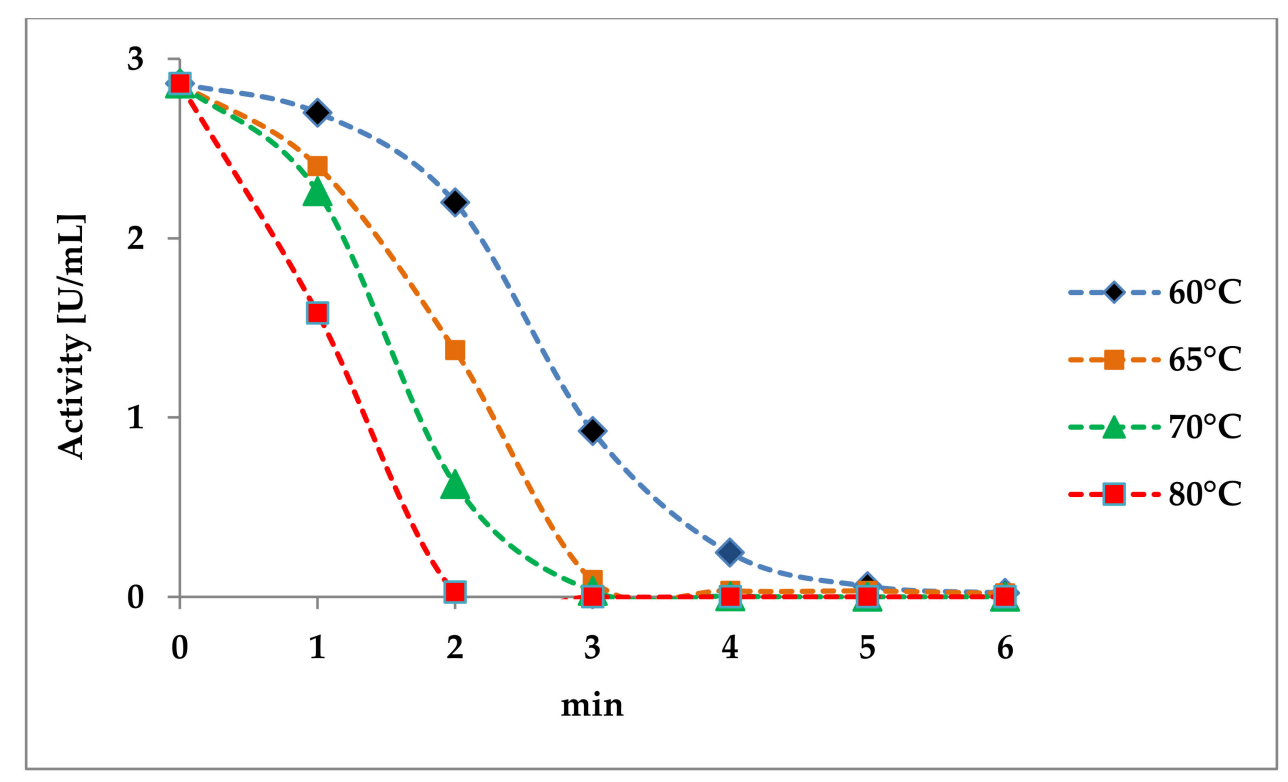

Figure 4. Influence of a heat treatment on must laccase [36].

\subsubsection{Addition of Sulphite}

The addition of $200 \mathrm{mg} / \mathrm{L}$ sulphite completely inactivated the must laccase in our previous experiments (Figure 5). Neither prolonged aeration nor dialysis, or the addition of copper restored the laccase activity of these samples. The effect of high sulphite concentrations is, thus, based on an irreversible inhibition of the protein itself and not on the reduction of the oxygen required for enzyme catalysis [36]. 


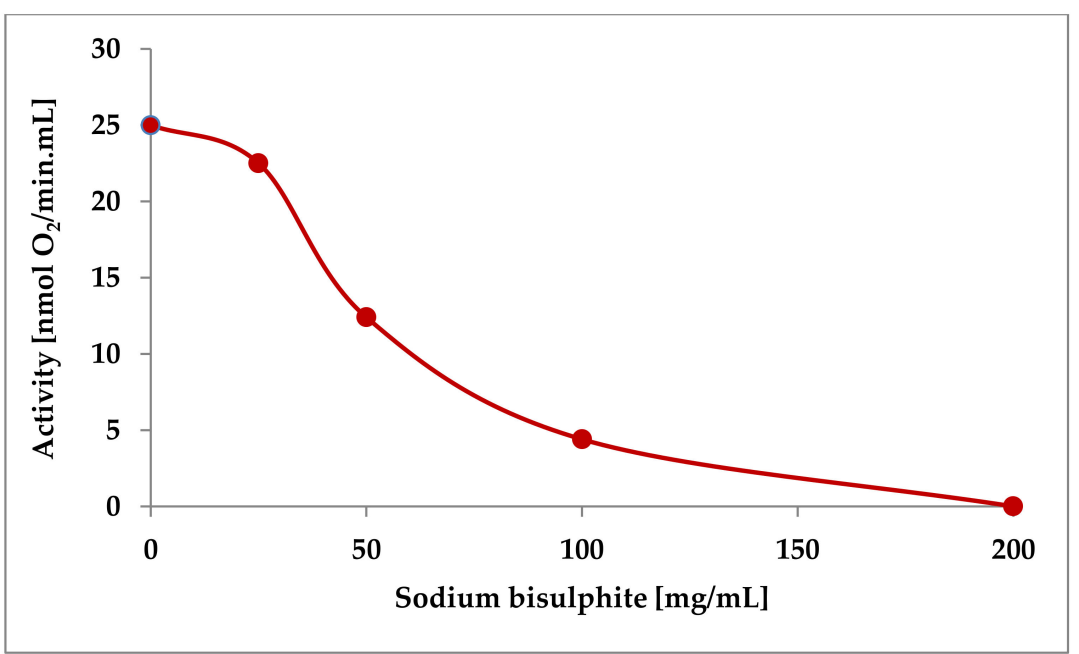

Figure 5. Influence of sulphite additions on the activity of a must laccase [36].

However, any heat treatment has a negative influence on the aroma profile of wine and sulphite and can lead to wine intolerance [37]. Thus, more effective antioxidants or laccase inhibitors would be better alternatives.

\subsubsection{Bentonite as A Fining Agent for Must and Wine Clarification}

The clay mineral bentonite is one of the most frequently used fining agents in the wine industry $[12,13,16,38-40]$. It is mostly used for clarification and protein binding. It is an aluminium hydrosilicate that belongs to the group of leaf structure silicates. Due to different histories of origin, there are different types of natural bentonite, which in turn can be modified in many ways. Sodium bentonite is predominantly coated with $\mathrm{Na}^{+}$ions in the interlayers, but $\mathrm{Ca}^{2+}$ or $\mathrm{Mg}^{2+}$ ions can also be present in various quantities. Sodium bentonite is characterized by a strong swelling and adsorption capacity. Calcium bentonite is almost exclusively covered with $\mathrm{Ca}^{2+}$ or $\mathrm{Mg}^{2+}$ ions in the interlayers. It has a moderate to good swelling and adsorption capacity. "Active" bentonite (Ca-Na bentonite) is originally a calcium bentonite in which the original cation coating of the intermediate layers is replaced by $\mathrm{Na}^{+}$ions by means of alkaline activation.

Bentonite acts as a cation exchanger and adsorbs mainly positively charged proteins. As already mentioned, bentonite has a platelet-like layer structure. Water molecules can be stored between these layer packages. This increases the distance between the layers. During this inner-crystalline swelling, a negative excess charge is built up within the layer packages, which is compensated by the accumulation of exchangeable cations $\left(\mathrm{Ca}^{++}, \mathrm{Mg}^{++}\right.$or $\left.\mathrm{Na}^{+}\right)$. Consequently, positively charged ions can be exchanged for positively charged wine proteins. In part, negatively charged proteins can also be exchanged, since the corners of the layers are positively charged.

The binding properties of the proteins to bentonite depend strongly on their isoelectric point $(\mathrm{pI})$. In general, the following relationship exists: the smaller the differences between wine or must $\mathrm{pH}$ and protein pI, the lower the net charge of the protein and the weaker is its binding. The greater the difference between wine or must $\mathrm{pH}$ and protein $\mathrm{pI}$, the greater the net charge of the protein and the better are its binding properties for bentonite.

In order to exploit the full effectiveness, bentonites must be preswollen in water. This results in a greater distance between the silicate lamellae, and thus a larger adsorption volume and increased absorption capacity. The swelling time should be between 4 and 12 hours. If necessary, bentonite can also be dissolved directly in the wine or grape juice. However, this can reduce its binding properties by up to $50 \%$.

Sodium bentonite is usually used for this purpose due to its stronger protein binding properties. In a study by Blade and Boulton [41] the binding of bovine serum albumin (BSA) in a wine model solution took place after only $30 \mathrm{~s}$. 


\subsubsection{Influence of Bentonite on Laccase Activity?}

As investigated by Jaeckels et al. [40], different wine proteins were bound to bentonites to different degrees and it was unclear how they interacted with enzymatically active laccases in must and wine. Claus and Filip [42] published a study on the effect of different protein adsorbents, including bentonites, on the adsorption and activity of phenol oxidases in buffer solutions. Among the phenol oxidases tested were laccases from Polyporus versicolor and Pleurotus ostreatus. The experiments showed that different phenol oxidases bound to bentonite to different degrees. The binding was dependent on the cation exchange capacity of the bentonite species and the $\mathrm{pH}$ value of the buffer solution. The two laccases mentioned above bound very well to aluminium-silica bentonite and the measured activity in the samples was even zero at $\mathrm{pH}$ values $<3.0$. It was also found that the enzyme activity of the bound phenol oxidases had decreased as compared with the initial activity. This means that bentonite also had an inhibitory effect on the enzyme activity.

The only question is, "can the laccases also be bound and inactivated so effectively in wine and grape juice?" In the work of Zivkovic et al. [36], must with laccase activity and, for comparison, the laccase PpL from Polyporus pinisitus, as well as two different types of bentonite, were used, i.e., $\mathrm{NaCalit}^{\circledR}$ (a granulated Na-Ca bentonite) and SodiBent Supra ${ }^{\circledR}$ (a natural fine powdered Na-bentonite) both purchased from Erbslöh Geisenheim AG (Geisenheim, Germany). These were used in different concentrations and the effect was tested in grape juice and wine at different $\mathrm{pH}$ values (Figure 6). In grape juice and must (not shown), the bentonites used had only a minor effect, even in high concentrations. In water and white wine, on the one hand, binding and inactivation of laccase was detected, with Na-bentonite being the far more effective clay preparation. In red wine, on the other hand, bentonite, particularly the Na-Ca bentonite, even stimulated the activity of the $P p L$ laccase. The oxidases apparently remained in solution in their active form, which resulted in discoloration of the red wine samples. The VIS spectra confirmed these browning reactions (Figure 7).
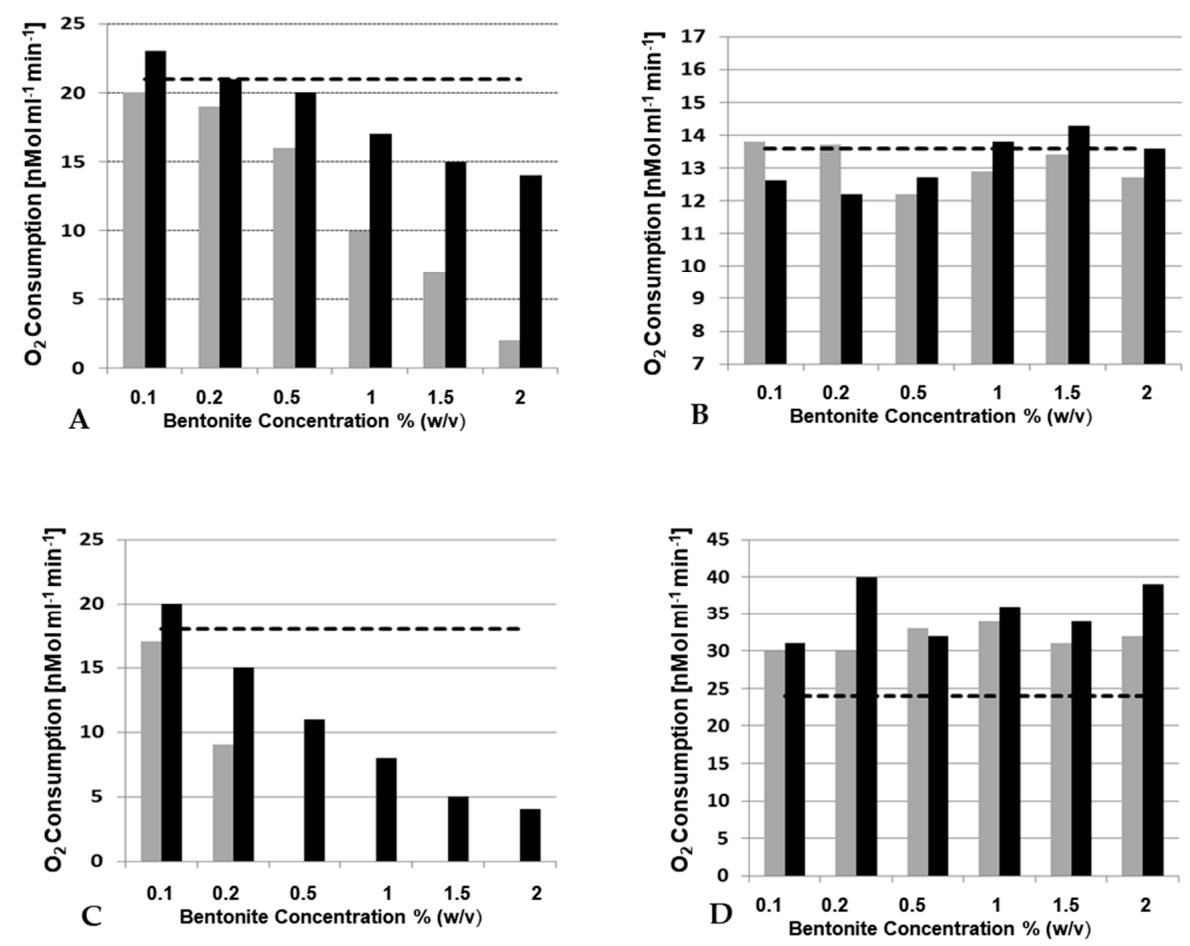

Figure 6. Effect of different bentonite concentrations on laccase $P p L$ [36]. (A) in water; (B) in white grape juice; (C) in white wine; and (D) in red wine. Activity measurement in the supernatants was performed after one hour incubation at $20{ }^{\circ} \mathrm{C}$ by measururing the oxygen consumption by laccase (substrate $5 \mathrm{mM}$ caffeic acid). The horizontal dotted lines mark the laccase activity without bentonite additions. Grey columns, Sodibent Supra ${ }^{\circledR}$ and black columns, NaCalit ${ }^{\circledR}$. 


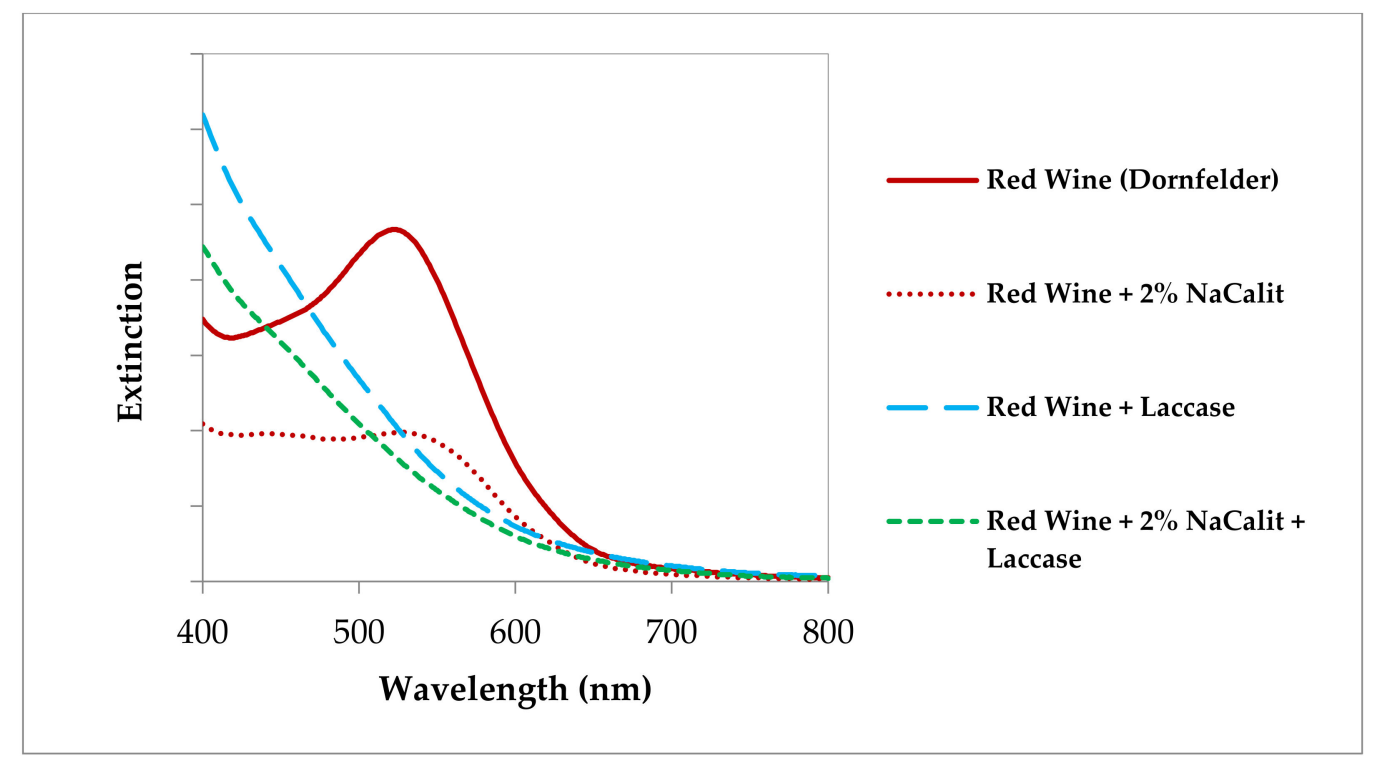

Figure 7. VIS spectra of a Dornfelder red wine after incubation with a model laccase from Polyporus pinisitus and in the presence of a Na-Ca-bentonite [36].

The binding properties of proteins to clay minerals generally depend very much on their isoelectric point [42]. The IEP of must laccase and $P p L$ is about 3.0. Most proteins removed by bentonite have a higher $\mathrm{pI}(5.8$ to 8.0$)[39,40]$. This can explain why $P p L$ has not completely bound laccase to bentonite in water, since aqueous bentonite suspensions have alkaline $\mathrm{pH}$ values $(\mathrm{pH}>8.0)$. This would mean that the laccase $P p L$ in these samples tends to be negatively charged, and therefore is not, or is only slightly, bound to the negatively charged bentonite.

One possible explanation for the low binding of laccase to bentonite in must and grape juice is their relatively high protein content. This is about 10 times higher in grape juice ( 2 to $3 \mathrm{~g} / \mathrm{L}$ ) than in wine. Thus, the protein binding sites of the bentonites were already predominantly occupied and laccase as an acid glycoprotein was hardly bound in this environment.

In white wine, a good effect of bentonite on laccases was found; this was to be expected at the acidic $\mathrm{pH}$ values (3.0 to 3.5) of these wines. In some papers, it was mentioned that the binding properties of bentonite increased with alcohol concentration [39]. The wines used in our own experiment [36] contained 12\% (Müller Thurgau) and 11.5\% alcohol (Pfälzer Landwein). This would explain the good binding properties here. Nevertheless, the question remains open as to why bentonite in red wine, which is also acidic and contains $11.5 \%$ alcohol, did not bind but even showed a stimulating effect on laccase. Red wines contain about 10 times more phenols than white wines [34]. Presumably, these wine ingredients of red wine were preferentially bound to bentonite [43], and thus potential inhibitors (tannins) for laccase activity were removed at the same time. The VIS spectra have also clearly shown that bentonite alone changes the color of red wine, i.e., binds anthocyanins.

\subsubsection{Ooenological Tannins to Eliminate Laccase Activities in Wine}

In general, tannins are divided into the following two major groups: (i) hydrolysable tannins (including gallotannins and ellagitannins) and (ii) condensed tannins (proanthocyanidins). Individual types of tannins differ in origin, chemical composition, and properties. The application of oenological tannins for winemaking has been approved by the International Organisation of Vine and Wine (OIV, 2015). Commercial oenological tannins are mainly used for fining of must and wine, as well as for improvement and stabilization of red wine color. With regard to the interaction with proteins, oenological tannins support protein refinement and prevent protein haze. They are also used as antioxidants and to improve wine structure and mouthfeel. Depending on the desired effect, they are added at doses ranging from 5 to $100 \mathrm{~g} / \mathrm{hL}$ [44-46]. 
The results of Vignault et al. $[45,46]$ showed that contrary to bentonite, particularly gallotannin, grape-skin and grape-seed tannin reduced laccase activity and altered its kinetic properties. The efficiency of grape-seed tannin addition in order to reduce the laccase activity was comparable to that of ascorbic acid or $\mathrm{SO}_{2}$ at the typical doses employed in oenology for each one. Oenological tannins appear to be excellent processing aids to prevent laccase effects and contribute to reduce the use of $\mathrm{SO}_{2}$ in grapes and musts.

\section{Conclusions}

It is known that the surface protein (S-layer) of lactobacilli can effectively bind metal ions by negatively charged carboxyl and phosphorous residues on their surface $[47,48]$. In this way, toxic copper ions could be excluded from the cell interior. Previous results do not exclude the possibility of using biomass of wine-relevant lactobacilli as an instrument to reduce elevated $\mathrm{Cu}$ concentrations from beverages containing wine $[15,22,24]$. Since lactobacilli have GRAS (General Recognized As Safe) status [49], there are no obvious risks for the consumer. Such an approach bears fewer risks than "bluefining" with potassium hexacyanoferrate (II). Synthetic polymers such as PVI-PVP could release toxic residual monomers, impurities, or degradation products into the wine [17,18]. Clay minerals such as bentonite are often used for wine fining. Their metal binding capacity depends strongly on the type used and as a result of the treatment, the concentrations of other metals such as calcium and zinc increase in the wine [19].

From a practical point of view, it seems to be a disadvantage that relatively high biomass concentrations $(0.05$ to $0.1 \% w / v)$ are required for effective metal removal, but this is also true for recommended dosages of bentonites $(\sim 0.2 \% w / v)$ and synthetic polymers $(0.05 \% w / v)$. Economic metal removal could be achieved by using reusable immobilized biomass or by direct inoculation of viable cells. For some time now, selected lactic acid bacteria, for example, strains of L. plantarum (Enoferm V22, Lallemand) have been offered and used in winemaking in addition to pure yeasts. In a similar approach as in the present study, it was investigated to what extent oenological lactic acid bacteria can serve as a tool to remove mycotoxins such as ochratoxin A [50]. Yeasts were also discussed for the biosorption of copper [51], but according to Huang et al. [20], the wine yeast Saccharomyces cerevisiae with $0.8 \mathrm{ug} \mathrm{Cu} / \mathrm{mg}$ (living biomass) or $0.4 \mu \mathrm{g} \mathrm{Cu} / \mathrm{mg}$ (dead biomass) was less effective in this respect (Table 2). Further investigations should focus on improved efficiency of biosorption and its possible effects on the chemical and sensory properties of wines.

B. cinerera laccase exerts serious negative effects on wine quality due to browning reactions triggered by the oxidation of phenols. Due to its high stability in alcohol and relative resistance to sulphite, inactivation of this enzyme is difficult, with the exception of a problematic heat treatment. Bentonite was found to be ineffective for eliminating laccase activities in must and red wine, although it inactivated laccase activity in white wine. However, it should be considered that for technical reasons the original Botrytis laccase was not used in these experiments but that of another fungus. Therefore, there is still a need for further research and development of novel effective measures to solve this problem. Application of oenological tannins appears to be a promising tool in this respect.

Funding: This research received no external funding

Acknowledgments: H.C. thanks all responsible persons, respected colleagues, and students at the Institute for Microbiology and the Wine Research of the Johannes Gutenberg University Mainz for their invaluable support during 20 years of scientific work. This contribution is dedicated to the memory of Prof. Heinz Decker.

Conflicts of Interest: The author declares no conflict of interest.

\section{References}

1. Singleton, V.L. Oxygen with phenols and related reactions in musts, wines, and model systems: Observations and practical implications. Am. J. Enol. Vitic. 1987, 38, 69-77.

2. Li, H.; Guo, A.; Wang, H. Mechanisms of oxidative browning of wine. Food Chem. 2008, 108, 1-13. [CrossRef] 
3. Sioumis, N.; Kallithraka, S.; Tsoutsouras, E.; Makris, D.P.; Kefalas, P. Browning development in white wines: Dependence on compositional parameters and impact on antioxidant characteristics. Eur. Food Res. Technol. 2005, 220, 326-330. [CrossRef]

4. Claus, H.; Sabel, A.; König, H. Wine Phenols and Laccase: An ambivalent relationship. In Wine: Phenolic Composition, Classification and Health Benefits; El Rayess, Y., Ed.; Nova Publishers: Hauppauge, NY, USA, 2014; pp. 155-185.

5. Claus, H. Laccases of Botrytis cinerea. In Biology of Microorganisms on Grapes, in Must and Wine, 2nd ed.; König, H., Unden, G., Eds.; Springer: Berlin/Heidelberg, Germany, 2017; pp. 339-356.

6. Fronk, P.; Riebel, M.; Decker, H. Polyphenol oxidase from wine grapes. In Biology of Microorganisms on Grapes, in Must and Wine, 2nd ed.; König, H., Unden, G., Eds.; Springer: Berlin/Heidelberg, Germany, 2017; pp. 357-374.

7. Riebel, M.; Sabel, A.; Claus, H.; Xia, N.; Li, H.; König, H.; Decker, H.; Fronk, P. Antioxidant capacity of phenolic compounds on human cell lines as affected by grape-tyrosinase and Botrytis-laccase oxidation. Food Chem. 2017, 229, 779-789. [CrossRef] [PubMed]

8. Claus, H. Copper-containing oxidases: Occurrence in soil microorganisms, properties and applications. In Soil Heavy Metals, Soil Biology Vol. 19; Sherameti, I., Varma, A., Eds.; Springer: Berlin/Heidelberg, Germany, 2010; pp. 281-313.

9. Araya, M.; Olivares, M.; Pizzaro, F. Copper in human health. Int. J. Environ. Health 2007, 1, 608-620. [CrossRef]

10. Wagner, E.; Augustin, T.; Brunn, H. Metallgehalt in Wein-Bestimmung in deutschen und ausländischen Weinen. Dtsch. Lebensm. Rundsch. 2010, 7, 385-388.

11. Nogueirol, R.C.; Alleoni, L.R.F.; Nachtigall, G.R.; de Melo, G.W. Sequential extraction and availability of copper in Cu fungicide-amended vineyard soil from Southern Brazil. J. Hazard. Mater. 2010, 181, 931-937. [CrossRef]

12. Zoecklein, B.W.; Fugelsang, K.C.; Gump, B.H.; Nury, F.S. Wine Analysis and Production; Springer: Boston, MA, USA, 1995.

13. Clark, A.C.; Wilkes, E.N.; Scollary, G.R. Chemistry of copper in white wine: A review. Aust. J. Grape Wine Res. 2015, 21, 339-350. [CrossRef]

14. Volpe, M.G.; la Cara, F.; Volpe, F.; de Mattia, A.; Serino, V.; Petitto, F.; Zavalloni, C.; Limone, F.; Pellecchia, R.; de Prisco, P.P.; et al. Heavy metal uptake in the enological food chain. Food Chem. 2009, 117, 553-560. [CrossRef]

15. Schut, S.; Claus, H.; König, H. Der Einsatz von Laktobazillen zur Entfernung von Kupfer aus Most und Wein. In Deutsches Weinbau Jahrbuch; Schultz, H.R., Stoll, M., Eds.; Ulmer Verlag Stuttgart: Stuttgart, Germany, 2012; pp. 137-145.

16. Ribéreau-Gayon, P.; Glories, Y.; Maujean, A.; Dubourdieu, S. Handbook of Enology, Vol 2, 2nd ed.; John Wiley \& Sons: Hoboken, NJ, USA, 2006; ISBN 978-0-470-01037-2.

17. Schubert, M.; Glomb, M.A. Analysis and chemistry of migrants from wine fining polymers. J. Agric. Food Chem. 2010, 58, 8300-8304. [CrossRef]

18. Mira, H.; Leite, P.; Catarino, S.; Ricardo-da-Silva, J.M.; Curvelo-Garcia, A.S. Metal reduction in wine using PVI-PVP colpolymer and its effects on chemical and sensory characters. VITIS 2007, 46, 138-147.

19. Ficagna, E.; Gava, A.; Rossato, S.B.; Rombaldi, C.V.; Borsato, D. Effect on Merlot red wine of fining agents mixture: Application of the simplex centroid design. Food Sci. Technol. 2020. [CrossRef]

20. Huang, C.P.; Huang, C.P.; Morehart, A.L. The removal of $\mathrm{Cu}(\mathrm{II})$ from dilute aqueous solution by Saccharomyces cerevisiae. Water Res. 1990, 24, 433-439. [CrossRef]

21. Junghans, K.; Straube, G. Biosorption of copper by yeasts. Biol. Met. 1991, 4, 233-237. [CrossRef] [PubMed]

22. Ibrahim, F.; Halttunen, T.; Tahvonen, R.; Salminen, S. Probiotic bacteria as potential detoxification tools: Assessing their heavy metal binding isotherms. Can. J. Microbiol. 2006, 52, 877-885. [CrossRef] [PubMed]

23. Hassan, S.H.A.; Kim, S.J.; Jung, A.Y.; Joo, J.H.; Oh, S.E.; Yang, J.E. Biosorptive capacity of Cd(II) and Cu(II) by lyophilized cells of Pseudomonas stutzeri. J. Gen. Appl. Microbiol. 2009, 55, 27-34. [CrossRef]

24. Schut, S.; Zauner, S.; Hampel, G.; König, H.; Claus, H. Biosorption of copper by wine-relevant lactobacilli. Int. J. Food Microbiol. 2011, 145, 126-131. [CrossRef]

25. Naja, G.M.; Murphy, V.; Volesky, B. Biosorption, Metals. In Encyclopedia of Industrial Biotechnology: Bioprocess, Bioseparation, and Cell Technology; Flickinger, M.C., Ed.; Wiley Online Library: Hoboken, NJ, USA, 2010. 
26. Hansda, A.; Kumar, V. Biosorption of copper by bacterial adsorbents: A review. Res. J. Environ. Tox. 2015, 9, $45-58$.

27. König, H.; Fröhlich, J. Lactic acid bacteria. In Biology of Microorganisms on Grapes, in Must and Wine, 2nd ed.; König, H., Unden, G., Eds.; Springer: Berlin/Heidelberg, Germany, 2017; pp. 3-41.

28. Naughton, D.P.; Petróczi, A. Heavy metal ions in wines: Meta-analysis of target hazard quotients reveal health risks. Chem. Cent. J. 2008, 2, 22. [CrossRef]

29. Pardo, R.; Herguedas, M.; Barrado, E. Biosorption of cadmium, copper, lead and zinc by inactive biomass of Pseudomonas putida. Anal. Bioanal. Chem. 2003, 376, 26-32. [CrossRef]

30. Mrvčić, J.; Prebeg, T.; Barišić, L.; Stanzer, D.; Bačun-Družina, V.; Stehlik-Tomas, V. Zinc binding by lactic acid bacteria. Food Technol. Biotechnol. 2009, 47, 381-388.

31. Mrvčić, J.; Stanzer, D.; Bačun-Družina, V.; Stehlik-Tomas, V. Copper binding by lactic acid bacteria (LAB). Biosci. Microflora 2009, 28,1-6. [CrossRef]

32. Cabuka, A.; Akar, T.; Tunali, S.; Gedikli, S. Biosorption of Pb(II) by industrial strain of Saccharomyces cerevisiae immobilized on the biomatrix of cone biomass of Pinus nigra: Equilibrium and mechanism analysis. Chem. Eng. J. 2007, 131, 293-300. [CrossRef]

33. Strong, P.J.; Claus, H. Laccase: A review of its past and its future in bioremediation. Crit. Rev. Environ. Sci. Technol. 2011, 41, 373-434. [CrossRef]

34. El Rayess, Y. Wine: Phenolic Composition, Classification and Health Benefits; Nova Publishers: New York, NY, USA, 2014; ISBN 978-1-63321-048-6.

35. De Leonardis, A.; Lustrato, G.; Macciola, V.; Ranalli, G. APpLication of chemical and physical agents in model systems to controlling phenoloxidase enzymes. Eur. Food Res. Technol. 2010, 23, 603-610. [CrossRef]

36. Zivkovic, K.; König, H.; Claus, H. Wirkung von Bentonit auf die Laccase-Aktivität in Most und Wein. Dtsch. Lebensm. Rundsch. 2011, 107, 575-582.

37. Campos, F.M.; Couto, J.A.; Hogg, T. Utilisation of natural and by-products to improve wine safety. In Wine Safety, Consumer Preference, and Human Health; Moreno-Arribas, M.V., Bartolomé Sualdea, B., Eds.; Springer: Cham, Switzerland, 2016; pp. 27-49.

38. Marchal, R.; Jeandet, P. Use of Enological additives for colloid and tartrate salt stabilisation in white wines and for improvement of sparkling wine foaming properties. In Wine Chemistry and Biochemistry; Moreno-Arribas, M.V., Polo, M.C., Eds.; Springer: New York, NY, USA, 2010; pp. 127-158.

39. Waters, E.J.; Colby, C.B. Proteins. In Wine Chemistry and Biochemistry; Moreno-Arribas, M.V., Polo, C., Eds.; Springer: New York, NY, USA, 2009; pp. 213-226.

40. Jaeckels, N.; Tenzer, S.; Rosch, A.; Scholten, G.; Decker, H.; Fronk, P. $\beta$-glucosidase removal due to bentonite fining during wine making. Eur. Food Res. Technol. 2015, 241, 253-262. [CrossRef]

41. Blade, H.; Boulton, R. Adsorption of protein by bentonite in a model wine solution. Am. J. Enol. Vitic. 1988, 39, 193-199.

42. Claus, H.; Filip, Z. Behaviour of phenoloxidases in the presence of clays and other soil-related adsorbents. Appl. Microbiol. Biotechnol. 1988, 28, 506-511. [CrossRef]

43. Stanković, S.; Jović, S.; Živković, J. Bentonite and gelatine impact on the red wine coloured matter. Food Technol. Biotechnol. 2004, 42, 183-188.

44. Versari, A.; du Toit, W.; Parpinello, G.P. Oenological tannins: A review. Aust. J. Grape Wine Res. 2013, 19, 1-10. [CrossRef]

45. Vignault, A.; Pascual, O.; Jourdes, M.; Moine, V.; Fermaud, M.; Roudet, J.; Canals, J.M.; Teissedre, P.L.; Zamora, F. Impact of enological tannins on laccase activity. OENO One 2019, 53. [CrossRef]

46. Vignault, A.; Gombau, J.; Jourdes, M.; Moine, V.; Canais, J.M.; Fermaud, M.; Roudet, J.; Zamora, F.; Teissedre, P.L. Oenological tannins to prevent Botrytis cinerea damage in grapes and musts: Kinetics and electrophoresis characterization of laccase. Food Chem. 2020. [CrossRef] [PubMed]

47. Selenska-Pobell, S.; Merroun, M. Accumulation of heavy metals by microorga nisms: Biomineralization and nanocluster formation. In Prokaryotic Cell Wall Compounds Structure and Biochemistry; König, H., Claus, H., Eds.; Springer: Berlin/Heidelberg, Germany, 2010; pp. 483-500.

48. Dohm, N.; Petri, A.; Schlander, M.; Schlott, B.; König, H.; Claus, H. Molecular and biochemical properties of the S-layer protein from the wine bacterium Lactobacillus hilgardii B706. Arch. Microbiol. 2011, 193, 251-261. [CrossRef] 
49. Lebeer, S.; Vanderleyden, J.; de Keersmaecker, S.C.J. Genes and molecules of lactobacilli supporting probiotic action. Microbiol. Mol. Biol. Rev. 2008, 72, 728-764. [CrossRef]

50. Del Prete, V.; Rodriguez, H.; Carrascosa, A.V.; de las Rivas, B.; Garcia-Murono, M.R. In vitro removal of ochratoxin A by wine lactic acid bacteria. J. Food Prot. 2007, 70, 2155-2160. [CrossRef]

51. Brandolini, V.; Tedeschi, P.; Capece, A.; Maietti, A.; Mazzotta, D.; Salzano, G.; Paparella, A.; Romano, P. Saccharomyces cerevisiae wine strains differing in copper resistance exhibit different capability to reduce copper content in wine. World J. Microbiol. Biotechnol. 2002, 18, 499-503. [CrossRef]

C 2020 by the author. Licensee MDPI, Basel, Switzerland. This article is an open access article distributed under the terms and conditions of the Creative Commons Attribution (CC BY) license (http://creativecommons.org/licenses/by/4.0/). 